Vol 10, Issue 10, 2017

\title{
EFFECT OF GOLD AND NICKEL NANOPARTICLES ON IMMUNE PROTEINS OF TOXOPLASMOSIS PATIENTS
}

\author{
SURA A ABDULSATTAR*, ABDULLAH H DRYWALL \\ Department of Chemistry, College of Science, Al-Mustansiriya University, Baghdad, Iraq. \\ Email: surasci@uomustansiriyah.edu.iq
}

Received: 01 June 2017, Revised and Accepted: 19 June 2017

\begin{abstract}
Objective: An interaction between a nanoparticle and the immune system is considered desirable when it may lead to various beneficial medical applications such as vaccines, delivery of drugs, antigens or therapeutics for inflammatory and autoimmune disorders. This study aims to evaluate the impact of some immune proteins by the presence of gold and nickel nanoparticles in sera of toxoplasmosis patients.
\end{abstract}

Methods: A total of 20 patients women with toxoplasmosis aged (20-40 year) attending Central Health Laboratory in Baghdad city for the period (November 2016 to February 2017) and 20 age-matched of women healthy as a control were included in this study.

Results: A non-significant increase in the activity and specific activity of protease in the sera of women infected with toxoplasmosis were observed in comparison to their values in the healthy $(\mathrm{p}>0.05)$. While a non-significant decrease in total protein values was reported. The results of effect of nanoparticles showed a decrease in the level of the enzyme in the presence of nanoparticles by $41.3 \%$, while the results showed that inhibition of nickel nanoparticles was greater and 43.8\%. The results indicated that IgA, IgG, and IgM levels were decreased in the presence of gold nanoparticles. In the same context, both IgA and IgG were shown to be inhibitory in the presence of nickel nanoparticles while the results showed activation of the IgM level with nickel nanoparticles.

Conclusion: We conclude from this study that other studies are required to confirm our results and therefore support the possibility of using nickel nanoparticles as a support for the treatment of toxoplasmosis through its dual effect first by reducing the protease, which is essential for survival of the parasite and second by activating IgM level, which enhances the immune defense of the body against the parasite.

Keywords: Immunoglobulin, Nanoparticle, Protease, Toxoplasmosis, Gold.

(C) 2017 The Authors. Published by Innovare Academic Sciences Pvt Ltd. This is an open access article under the CC BY license (http://creativecommons. org/licenses/by/4. 0/) DOI: http://dx.doi.org/10.22159/ajpcr.2017.v10i10.20359

\section{INTRODUCTION}

The immune system is a host defense system that protects against pathogens such as viruses, parasitic, and worms. Within an organism the immune system comprising many biological structures and processes [1]. Antibody commonly called immunoglobulin is a protein produced in the blood in response of B cells to the presence of pathogen (antigen) by binding with them and in activate or destroy it. The molecules that antibodies recognize can be quite specific on a particular bacterium or virus [2]. In immune cells, one of their component is proteases which its function are recognition and elimination of pathogen, signal processing, cell homeostasis, and they are regulated by dedicated inhibitors called protease inhibitors [3]. Toxoplasmosis is caused by the infection by the parasite Toxoplasma gondii. The infection produces a wide range of clinical syndromes in humans [4]. Most of them don't get sick, but for some people it causes serious problems, like people with weak immune systems and babies whose mothers become infected for the first time during pregnancy [5]. These problems include damage to the brain, eyes, and other organs [5]. Congenital toxoplasmosis is usually a subclinical infection. Toxoplasmosis is most often occurs among immunodeficient individuals in those with defects of T cell-mediated immunity [4]. Two classes of Toxoplasma antibodies may be found in the blood of someone is exposed to T. gondii: $\operatorname{IgM}$ and IgG [5].

Functionalized gold nanoparticles with controlled geometrical and optical properties are the subject of intensive studies and biomedical applications [6,7]. One area of interest involves the interactions between nanoparticles and the components of the immune system.
Nanoparticles can be designed to either avoid immune system recognition or specifically enhance or inhibit the immune responses [8]. When nanoparticles enter the body, their interactions with cells are almost unavoidable [8]. An interaction between a nanoparticle and the immune system is considered desirable when it may lead to various beneficial medical applications such as vaccines, delivery of drugs, antigens or therapeutics for inflammatory, and autoimmune disorders $[9,10]$. This study aims to evaluate the impact of some immune proteins by the presence of gold and nickel nanoparticles in sera of toxoplasmosis patients.

\section{METHODS}

A total of 20 patients women with toxoplasmosis aged (20-40 year) attending Central Health Laboratory in Baghdad city for the period (November 2016 to February 2017) and 20 age matched of women healthy as a control were included in this study. $5 \mathrm{~mL}$ of venous blood was collect from each sample, and placed in a plane tube, and left for (15 minutes) at room temperature to clot, then centrifuged at $3000 \mathrm{rpm}$ for 10 minutes. Serum that obtained was stored at $\left(-20^{\circ} \mathrm{C}\right)$ until they will be used. The activity of serum protease was determined using casein as substrate according to assay method of Ishaya et al. [11], with modification [12], and the specific activity of protease was expressed as $\mu \mathrm{mol} / \mathrm{g}$ of protein. Total protein was determined using colorimetric method of Biurite. IgG and IgM were measured using the single radial immune diffusion method. The LT Kit was used according to the company's instructions according to the Mancini et al. principle, describing the linear relationship between the concentration of the antigen and the radius an immunosorbent ring consisting of antibodies 
containing antibodies of antigen quality [13]. The nanoparticles used in this study consisted of gold nanoparticles and nickel nanoparticles [14], synthesized using pulsed laser ablation in liquid method [15].

\section{RESULTS AND DISCUSSION}

The results presented in Table 1 showed a non-significant increase in the activity and specific activity of protease in the sera of women infected with toxoplasmosis in comparison to their values in the healthy ( $p>0.05)$. While a non-significant decrease in total protein values was observed in those with toxoplasmosis in comparison to their values in the healthy ( $p>0.05$ ). It is worth mentioning that this study is the first to evaluate the level of protease in the sera of women infected with toxoplasmosis. Protease plays a crucial role in the degradation of proteins by decomposition. It is classified into seven categories based on the key catalase residues in an active location: Aspartic, cysteine, glutamic, serine, threonine, metallic, and chromium, which can be divided into more families [16]. This enzyme is important for the growth and survival of parasites in humans [17]. Lagal et al. reported that host cell invasion by $T$. gondii is critically dependent on adhesive proteins secreted from the micronemes. Proteolytic trimming of microneme contents occurs rapidly after their secretion onto the parasite surface and is proposed to regulate adhesive complex activation to enhance binding to host cell receptors [18].

The previous studies show that nanoparticles can stimulate or suppress the immune responses and that their compatibility with the immune system is largely determined by their surface properties. Where the size, shape, composition, protein binding, and administration routes of nanoparticles seem to be the main factors that contribute to the interactions with the immune system [19]. Fig. 1 shows the effect of gold and nickel nanoparticles on the level of protease in the sera of women with toxoplasmosis. The results showed a decrease in the level of the enzyme in the presence of nanoparticles by $41.3 \%$, while the results showed that inhibition of nickel nanoparticles was greater and $43.8 \%$.

Figs. 2-4 shows the average values of IgA, IgG, and IgM, and the effect of gold and nickel nanoparticles on their level, respectively, in the sera of women with toxoplasmosis. The results indicated that IgA, IgG, and IgM levels were decreased in the presence of gold nanoparticles. According to the previous studies on the association of gold with proteins, gold is linked with the active site of proteins, which leads to the denaturation [20]. In the same context, both IgA and IgG were shown to be inhibitory in the presence of nickel nanoparticles, while the results showed activation of the IgM level with nickel nanoparticles. IgM antibodies are the first to be produced by the body in response to toxoplasmosis and are present in most individuals within a week or two after exposure. This increase in immune globulin (antibody production) is for a short period of time and then decreases again. IgG is produced in the body after several weeks of initial infection to provide longterm protection [21]. Its levels rise during active infection, then settle as toxoplasmosis and parasites are inactive. The IgM antibody test, combined with the IgG test, can be used to help confirm the presence of a recent or earlier toxoplasmosis. Recent studies demonstrated increased Toxoplasma IgG, but not IgM, antibody levels in sera of patients with

Table 1: Mean values of total protein, activity and specific activity of protease in sera of studied groups

\begin{tabular}{llll}
\hline Parameter & Group & Mean \pm SD & p value \\
& & & \\
\hline Total protein $(\mathrm{g} / \mathrm{dL})$ & Control & $7.07 \pm 15.9$ & 0.17 \\
& Patients & $6.39 \pm 12.2$ & \\
Protease activity $(\mu \mathrm{mol} / \mathrm{L})$ & Control & $109.09 \pm 23.3$ & 0.387 \\
& Patients & $116.15 \pm 29.5$ & \\
Protease specific & Control & $1.542 \pm 0.87$ & 0.295 \\
activity $(\mu \mathrm{mol} / \mathrm{g})$ & & & \\
& Patients & $1.815 \pm 0.68$ & \\
\hline
\end{tabular}

SD: Standard deviation

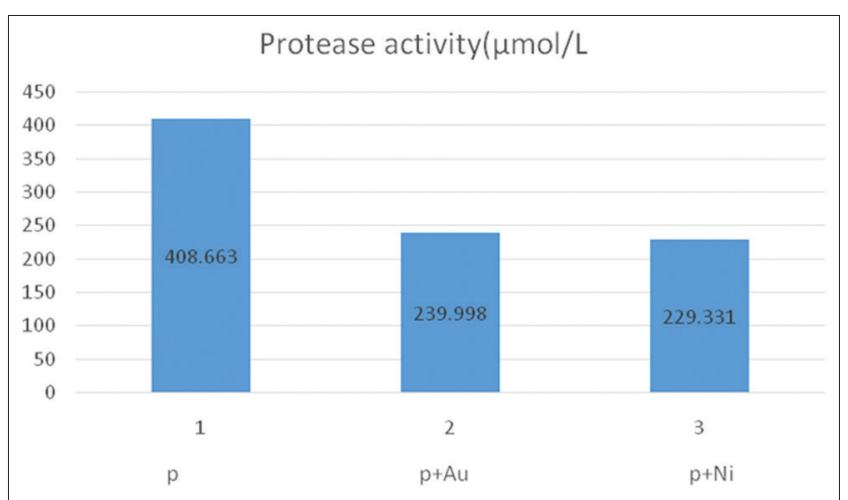

Fig. 1: Protease activity without and with gold and nickel nanoparticles in sera of toxoplasmosis

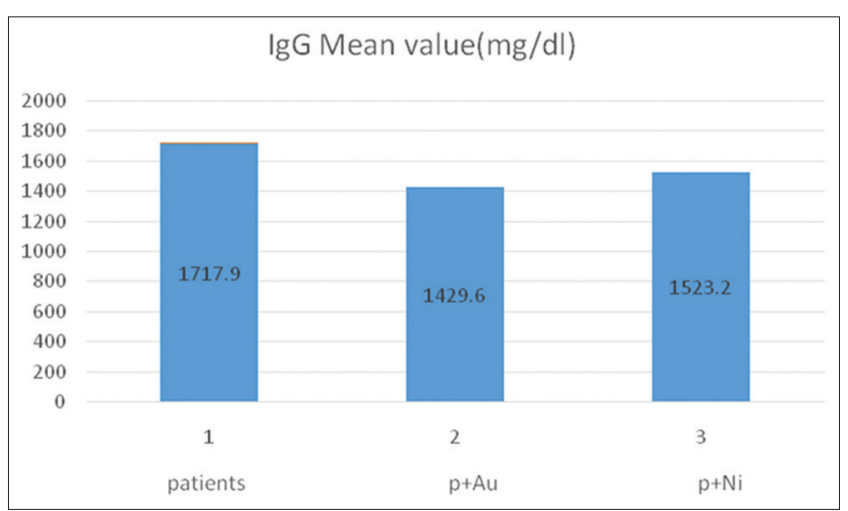

Fig. 2: IgG mean value in the absence and presence of gold and nickel nanoparticles in sera of toxoplasmosis

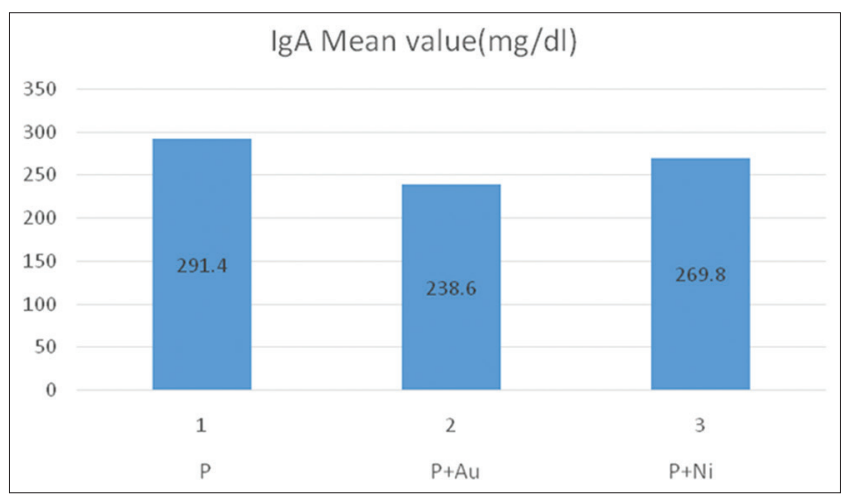

Fig. 3: IgA mean value in the absence and presence of gold and nickel nanoparticles in sera of toxoplasmosis

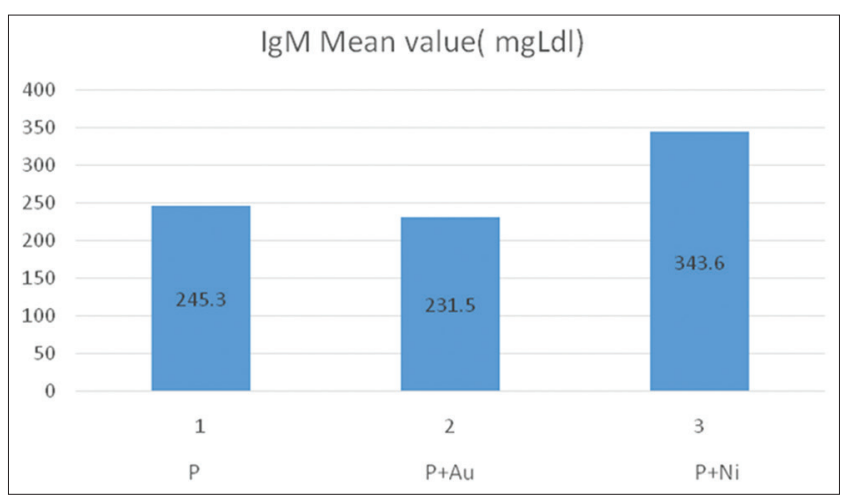

Fig. 4: IgM mean value in the absence and presence of gold and nickel nanoparticles in sera of toxoplasmosis 
recent onset of schizophrenia [22,23]. These schizophrenia patients do not appear to be in the acute stage of acquired infection with T. gondii, since both IgM and IgG antibody titers increase during this stage of infection [24]. Therefore, the patients appear to be in a specific condition of chronic infection that causes an increase only in IgG antibody titers [25]

\section{CONCLUSION}

We conclude from this study that other studies are required to confirm our results and therefore support the possibility of using nickel nanoparticles as a support for the treatment of toxoplasmosis through its dual effect first by reducing the protease, which is essential for survival of the parasite and second by activating of IgM, which enhances the immune defense of the body against the parasite.

\section{REFERENCES}

1. Beck G, Habitat GS. Immunity and the invertebrates. Sci Am 1996;275(5):60-6. doi:10.1038/scientificamerican1196-60.

2. American Heritage Dictionary. The American Heritage Student Dictionary. $2^{\text {nd }}$ ed. Boston: Houghton Mifflin Harcourt Publishing Company; 2014

3. Bird PI, Trapani JA, Villadangos JA. Endolysosomal proteases and their inhibitors in immunity. Nat Rev Immunol 2009;9(12):871-82.

4. Hökelek M. Toxoplasmosis . (Medscape) Updated, October, 24; 2016.

5. American Association for Clinical Chemistry. Available from: https:// www.medlineplus.gov/toxoplasmosis.html\#cat 59

6. Dykman LA, Khlebtsov NG. Gold nanoparticles in biology and medicine: Recent advances and prospects. Acta Naturae 2011;3(2):34-55.

7. Zhang X. Gold nanoparticles: Recent advances in the biomedical applications. Cell Biochem Biophys 2015;72(3):771-5.

8. Zolnik BS, González-Fernández A, Sadrieh N, Dobrovolskaia MA. Nanoparticles and the immune system. Endocrinology 2010;151(3):458-65.

9. Kononenko V, Narat M, Drobne D. Nanoparticle interaction with the immune system. Arh Hig Rada Toksikol 2015;66(2):97-108.

10. Dobrovolskaia MA, Shurin M, Shvedova AA. Current understanding of interactions between nanoparticles and the immune system. Toxicol Appl Pharmacol 2016;299:78-89.

11. Ishaya I, Swirski E. Trehalase invertase and amylase activities in the larvae of Egyptian cotton worm, Spodoptera littoralis (L). J Insect Physiol 1971;17(5):945-53.
12. Vitthalrao K, Sucheta DS. Protein contents and activity of enzymes in the mod gut homogenate of fifthinstar larvae of silkworm, Bombyx mori (L). (Race: PM x CSR2) fed withherbal drug(Kho-go) treated mulberry leaves. Res J Recent Sci 2012;1(2):49-55.

13. Mancini G, Carbonara AO, Heremans JF. Immunochemical quantitation of antigens by single radial immunodiffusion. Immunochemistry $1965 ; 2(3): 235-54$

14. Leitz KH, Redlingshöfer B, Reg Y, Otto A, Schmidt M. Metal ablation with short and ultrashort laser pulses. Phys Procedia 2011;12:230-8.

15. Abdulsattar AS, Hadi DH, Algam HH. Biochemical characterization of protease and its impact by nano particles in sera of Iraqi patients with burns. Med J Babylon 2015;12(4):870-81.

16. López-Otín C, Bond JS. Proteases: Multifunctional enzymes in life and disease. J Biol Chem 2008;283(45):30433-7.

17. Dou Z, Carruthers VB. Cathepsin proteases Toxoplasma gondii. In: Madame Curie Bioscience Database. Austin (TX): Landes Bioscience; 2000-2013.

18. Lagal V, Binder EM, Huynh MH, Kafsack BF, Harris PK, Diez R, et al. Toxoplasma gondii protease TgSUB1 is required for cell surface processing of micronemal adhesive complexes and efficient adhesion of tachyzoites. Cell Microbiol 2010;12(12):1792-808.

19. Najafi-Hajivar S, Zakeri-Milani P, Mohammadi H, Niazi M, SoleymaniGoloujeh M, Baradaran B, et al. Overview on experimental models of interactions between nanoparticles and the immune system. Biomed Pharmacother 2016;83:1365-78.

20. Chudasama B, Vala AK, Andhariya N, Mehta RV, Upadhyay RV. Highly bacterial resistant silver nanoparticles: Synthesis and antibacterial activities. J Nanopart Res. 2010;12(5):1677-85.

21. Newsholme E, Leech T. Functional Biochemistry in Health and Disease. Hoboken, NJ: Wiley-Blackwell Publishing; 2010. p. 385.

22. Leweke FM, Gerth CW, Koethe D, Klosterkötter J, Ruslanova I, Krivogorsky B, et al. Antibodies to infectious agents in individuals with recent onset schizophrenia. Eur Arch Psychiatry Clin Neurosci 2004;254(1):4-8.

23. Torrey EF, Yolken RH. Toxoplasma gondii and schizophrenia. Emerg Infect Dis 2003;9(11):1375-80.

24. Stommel EW, Seguin R, Thadani VM, Schwartzman JD, Gilbert K, Ryan KA, et al. Cryptogenic epilepsy: An infectious etiology? Epilepsia 2001;42(3):436-8

25. Hester J, Mullins J, Sa Q, Payne L, Mercier C, Cesbron-Delauw MF, et al. Toxoplasma gondii antigens recognized by $\operatorname{IgG}$ antibodies differ between mice with and without active proliferation of tachyzoites in the brain during the chronic stage of infection. Infect Immun 2012;80(10):3611-20. 